\title{
Quality Attributes of Chitosan-Coated Cornelian Cherry (Cornus mas L.) Fruits under Different Storage Temperatures
}

\author{
Asghar Ebrahimzadeh ${ }^{1, *}$, Maryam Esmaeili ${ }^{1}$, Hamid Hassanpour ${ }^{2}$, Mohammad Bagher Hassanpouraghdam ${ }^{1}(\mathbb{D}$, \\ Sezai Ercisli $^{3}{ }^{D}$, Mehmet Ramazan Bozhuyuk ${ }^{4}$, , Libor Dokoupil $^{5, *}$ and Jiri Mlcek ${ }^{6}{ }^{D}$ \\ 1 Department of Horticultural Science, Faculty of Agriculture, University of Maragheh, \\ Maragheh 55181-83111, Iran; salviaspectacular1@gmail.com (M.E.); hassanpouraghdam@gmail.com (M.B.H.) \\ 2 Department of Horticultural Science, Faculty of Agriculture, Urmia University, Urmia 57561-51818, Iran; \\ phhassanpour@gmail.com \\ 3 Department of Horticulture, Faculty of Agriculture, Ataturk University, Erzurum 25240, Turkey; \\ sercisli@gmail.com \\ 4 Department of Plant and Animal Production, Vocational School of Technical Sciences, Igdir University, \\ Igdir 76100, Turkey; mrbozhuyuk@gmail.com \\ 5 Department of Breeding and Propagation of Horticultural Plants, Faculty of Horticulture, \\ Mendel University in Brno, Valtická 337, 69144 Lednice, Czech Republic \\ 6 Department of Food Analysis and Chemistry, Faculty of Technology, Tomas Bata University in Zlín, \\ Vavreckova 275, 76001 Zlín, Czech Republic; mlcek@utb.cz \\ * Correspondence: acebrahimzadeh@gmail.com (A.E.); libor.dokoupil@mendelu.cz (L.D.); \\ Tel.: +98-9147783936 (A.E.); Tel.: +42-0545136003 (L.D.)
}

Citation: Ebrahimzadeh, A.; Esmaeili, M.; Hassanpour, H.; Hassanpouraghdam, M.B.; Ercisli, S.; Bozhuyuk, M.R.; Dokoupil, L.; Mlcek, J. Quality Attributes of

Chitosan-Coated Cornelian Cherry (Cornus mas L.) Fruits under Different Storage Temperatures. Horticulturae 2021, 7, 540. https://doi.org/ 10.3390/horticulturae7120540

Academic Editor: Mohammad Zahirul Islam

Received: 30 September 2021 Accepted: 18 November 2021 Published: 2 December 2021

Publisher's Note: MDPI stays neutral with regard to jurisdictional claims in published maps and institutional affiliations.

Copyright: (c) 2021 by the authors. Licensee MDPI, Basel, Switzerland. This article is an open access article distributed under the terms and conditions of the Creative Commons Attribution (CC BY) license (https:// creativecommons.org/licenses/by/ $4.0 /)$.

\begin{abstract}
Temperature is the dominant environmental stimulus that influences the postharvest quality, visual appearance, and nutritional content of fruits. Temperature hastens fruit ripening and senescence by the impact on respiration rate and the acceleration of metabolic reactions. This study was conducted to select the optimized temperature for preserving the quality-related traits and antioxidant potential of cornelian cherry fruits after harvest. The fruits were treated with $1 \%$ chitosan and then kept under $0,5,10$, and $21^{\circ} \mathrm{C}$ for 21 days. The results revealed that fruits kept under lower than room temperature $\left(21^{\circ} \mathrm{C}\right)$ better retained antioxidant capacity and had higher levels of phenolics, flavonoids, and anthocyanins and even higher antioxidant enzyme activity, hence attaining prolonged postharvest life. Considering the quantity attributes and the shelf life, the temperature of choice was $0{ }^{\circ} \mathrm{C}$. Zero temperature was also the best to keep the antioxidant capacity of cornelian cherry fruits. Overall, the results showed that low temperature and chitosan pretreatment provide an efficient method for maintaining the nutritional quality and antioxidant capacity of cornelian cherry fruits during storage time.
\end{abstract}

Keywords: antioxidant capacity; chitosan; cornelian cherry; fruit ripening; phenolics; postharvest

\section{Introduction}

Horticultural products contain several biological and beneficial compounds capable of scavenging reactive oxygen species (ROS) molecules and, hence, protecting the cells and metabolic pathways from the deteriorative effects of those molecules [1,2]. Moreover, antioxidants protect the human body and prevent coronary diseases, cancer, and agerelated disorders [3].

The Cornus mas L. shrub belongs to the Cornaceae family [4]. Cornelian cherry has elliptical stone fruits, pink-, yellow-, and/or red-colored with sour tasty flavor [5]. Cornelian cherry fruit is a rich source of natural antioxidants, anthocyanins [6], vitamin C, organic acids (mainly malic acid), pectin, phenolic acids, flavonoids, and some other constituents [7-9]. Biological functions of cornelian cherry fruits such as anticancer, antiviral, immune system protectant, and hypolipidemic activities are attributed to the ROS scavenging and antioxidant 
activities. Hence, the great antioxidant potential of cornelian cherries is of increasing interest to researchers surveying this fruit during the postharvest period [10].

Postharvest application of edible coatings such as chitosan is an efficient and sustainable technique to increase shelf life and decrease postharvest losses of fresh fruits and vegetables. This environmentally friendly treatment can help lower the respiration rate, delay the ripening process, and control microbial growth rates in harvested fresh produce [11]. An antifungal property $[12,13]$ and the slowing of ripening and senescence process by the control of $\mathrm{CO}_{2}, \mathrm{O}_{2}$, and ethylene exchange balance are the other beneficial effects of chitosan coating [14]. Single chitosan coating sometimes demonstrates certain defects or limitations including the restricted control of specific microorganisms, poor coating adjustment, and the permeability of the cells. Hence, to obtain more efficiency, the recommendation is to use chitosan with other substances such gum arabic, ethanol, wax, and some other organic and inorganic compounds [11] or in combination with nanoparticles including submicron chitosan [15]. Moreover, sole chitosan coating has often been integrated with physical methods including gas fumigation, modified atmosphere packing (MAP), and postharvest temperature management [11].

On the other hand, temperature management is the most influential factor in the postharvest life of perishable horticultural crops. Earlier studies demonstrated that lowtemperature storage intensifies the preserving effects of chitosan on stored fruits. The temperature outcome has been extensively evaluated in postharvest studies; however, some naturally grown fruits such as cornelian cherry fruits still await detailed studies to decide on the optimized postharvest storage temperature.

Moreover, investigations on the integrated physicochemical treatments using chitosan (postharvest chemical treatment) followed by storage temperature management (as a physical treatment) is a subject that demands a deeper realization capacity. Therefore, the present study aimed to evaluate the effects of storage temperature on the quality and storage life of chitosan-coated cornelian cherry fruits.

\section{Materials and Methods}

\subsection{Plant Materials}

Cornelian cherry fruits (Cornus mas L.) were harvested during the early morning of September 2017, according to the uniformity of size and color, from Injar village, Horand county, Northwest Iran ( $\left.38^{\circ} 8^{\prime} \mathrm{N}, 47^{\circ} 37^{\prime} \mathrm{E}\right), 950 \mathrm{~m}$ about sea level. Soon after harvest, the fruits were transported to the Postharvest Physiology of Horticultural Crops Laboratory at the University of Urmia, Iran. Based on the previous experiments in our lab [16], among $0.5,1$, and $1.5 \%(w / v)$ concentrations, $1 \%$ chitosan solution was selected for further studies with coating treatments.

Crab shell chitosan (analytical grade purchased from Sigma-Aldrich, Madrid, Spain) aqueous solution was prepared by using acetic acid, and the final volume was reached with distilled water. For homogenization, the solution was heated and stirred for $2 \mathrm{~h}$, and then its $\mathrm{pH}$ was adjusted to 5.6 with $1.0 \mathrm{~N} \mathrm{NaOH}$. Then, for chitosan coating treatment, the fruits were immersed in $1 \%$ chitosan solution for $5 \mathrm{~min}$. The coated fruits were allowed to completely dry at room temperature. Subsequently, 1800 fruits were selected and divided into 4 lots of 450 , which were stored for three weeks at 0,5 , and $10^{\circ} \mathrm{C}$, as well as $21^{\circ} \mathrm{C}$ (ambient room temperature) as control. Fifty fruits per replicate of each treatment were taken from cold storage every week to measure fruit firmness and color analysis; after stone extraction, mesocarp of fruits was mixed, frozen immediately in liquid nitrogen, and stored at $-80^{\circ} \mathrm{C}$ for further analyses.

Fruit firmness was tested by an automatic texture analyzer (TA-XT plus Texture Analyzer, Stable Micro Systems, Godalming, UK) based on kg force per area.

For colorimeter analysis, a Minolta (CR400, Osaka, Japan) instrument was used. 


\subsection{Titratable Acidity, Total Soluble Solids, and $p H$}

The method of Selcuk and Erkan [17] was followed to measure $\mathrm{pH}$, titratable acidity (TA), and total soluble solid (TSS) content in cornelian cherry fruit extracts.

The titratable acidity (TA) was determined by titration of juice with $0.1 \mathrm{M} \mathrm{NaOH}$ (Sigma-Aldrich, Merck, Madrid, Spain) using phenolphthalein (Sigma-Aldrich, Merck) as an indicator until reaching the extract $\mathrm{pH}$ of 8.2. The results were calculated as the mean value of three experiments and expressed as the percentage of citric acid.

The total soluble solid (TSS) content of fruits was measured using a portable refractometer (ATAGO PR = 32, ATAGO Co., Ltd., Tokyo, Japan).

$\mathrm{pH}$ was quantified by a $\mathrm{pH}$ meter (AZ8601, Taichung, Taiwan) at room temperature $\left(23^{\circ} \mathrm{C}\right)$.

\subsection{Total Phenolic Content and 2,2-Diphenyl-1-picrylhydrazyl (DPPH) Scavenging Capacity}

To evaluate the above traits, fruits were extracted by the method of Selcuk and Erkan [17]. Total phenolic (TP) content was determined according to the Folin-Ciocalteu procedure. The absorbance was measured by UV/Vis spectrophotometer (PC-1650; Shimadzu Kyoto, Japan) and expressed in mg gallic acid equivalent (GAE) per $\mathrm{g}$ fresh weight (FW) of fruit.

To evaluate the extract potential to scavenge free radicals (DPPH assay), the sample absorbance was recorded at $517 \mathrm{~nm}$ [18] and the data were calculated based on the following formula:

$$
\text { Inhibition of DPPH }=[(\text { Abs control }- \text { Abs sample }) / \text { Abs control }] \times 100
$$

where Abs control is the absorbance of DPPH solution without extract.

\subsection{Total Anthocyanin Content}

Anthocyanins were assayed based on the absorbance difference at different $\mathrm{pH}$ ranges [19]. The first buffer $(\mathrm{pH}=1)$ was prepared with potassium chloride $(\mathrm{KCl}) 0.2$ $\mathrm{M}$, and for the second buffer ( $\mathrm{pH}=4.5), 0.2 \mathrm{M}$ acetic acid was employed. Anthocyanin content was read at 520 and $700 \mathrm{~nm}$. The total anthocyanins were calculated according to the following equation based on cyanidin-3-glucoside:

$$
(\mathrm{A})=(\mathrm{A} 520 \mathrm{pH} 1-\mathrm{A} 700 \mathrm{pH} 1)-(\mathrm{A} 520 \mathrm{pH} 4.5-\mathrm{A} 700 \mathrm{pH} 4.5)
$$

\subsection{Total Flavonoids (TF) Content}

Total flavonoids were measured based on the method of Shin et al. [20] as mg catechin/g FW.

\subsection{Antioxidant Capacity}

The antioxidant capacity of extracts was calculated as the inhibition percentage of DPPH using the method of Aebi [21].

\subsection{PAL, PPO, and GPX Activity}

Phenylalanine ammonia-lyase (PAL) activity was assayed based on cinnamic acid production according to Nguyen et al. [22] and was expressed as $\mu$ mol cinnamic acid $\mathrm{mg}^{-1}$ protein $\mathrm{h}^{-1}[1,2]$. Polyphenol oxidase (PPO) was assayed by measuring the oxidation of catechol as substrate according to Nguyen et al. [22] and was expressed as $\mathrm{U} / \mathrm{mg}$ protein.

Guaiacol peroxidase (GPX) activity was measured by the method of Upadhyaya et al. [23] as absorbance increasing pattern in min at $490 \mathrm{~nm}$. The activity of catalase (CAT) enzyme was determined according to Aebi [18], and the absorption reduction was recorded at $240 \mathrm{~nm}$ for $60 \mathrm{~s}$. 


\subsection{Statistical Analysis}

The experiment was designed as factorial based on a completely randomized design (CRD) with 3 replications. Data analysis of variance (ANOVA) was performed using IBM SAS software (Version 9.2), and the differences between means were assessed using Duncan's multiple range test at $p \leq 0.05$ and $p \leq 0.01$.

\section{Results and Discussion}

\subsection{Fruit Firmness}

ANOVA (Table 1) showed the significant $(p \leq 0.01)$ difference in fruit firmness under different storage temperatures. The top firmness value of $0.55 \mathrm{~kg} \cdot \mathrm{cm}^{-2}$ was found for the first day, and firmness decreased day by day (Figure 1). The firmness of the fruits kept at room temperature was near zero (Figure 1). Firmness index is a dominant physical parameter in fruit quality recognition, ripeness determination, storage capability, and marketability potential [24-26].

Table 1. ANOVA for the fruit firmness, $\mathrm{pH}$, TSSs, and color indices in cornelian cherry fruits treated with $1 \%$ chitosan under different storage temperatures.

\begin{tabular}{|c|c|c|c|c|c|c|c|c|c|c|}
\hline & & & & MS & & & & & DF & sS \\
\hline Chroma & Hue & $\mathbf{b}^{*}$ & $a^{*}$ & $\mathbf{L}^{*}$ & TSSs & TA & $\mathrm{pH}$ & Firmness & & \\
\hline$* * 121.038$ & $3.58^{\mathrm{ns}}$ & $* * 23.87$ & $* * 97.48$ & $* * 44.54$ & $* * 37.34$ & $* * 1.16$ & $* * 0.05$ & $* * 0.28$ & 3 & Temperature \\
\hline ** 1094.68 & ** 476.01 & $* * 717.20$ & ** 510.58 & $\begin{array}{c}* * \\
1089.19\end{array}$ & $* * 44.12$ & $* * 11.98$ & ** 0.40 & $* * 0.18$ & 3 & Day \\
\hline$* * 46.32$ & $* * 23.84$ & $* * 13.60$ & $* * 37.24$ & ** 19.61 & $* * 6.27$ & ** 0.47 & $* * 0.03$ & $* * 0.044$ & 9 & Day $\times$ Temperature \\
\hline 3.02 & 5.39 & 1.05 & 2.9 & 1.76 & 0.46 & 0.02 & 0.0016 & 0.001 & 32 & Error \\
\hline 6.17 & 8.31 & 7.44 & 6.99 & 3.81 & 4.50 & 8.64 & 1.28 & 8.31 & - & C.V. \\
\hline
\end{tabular}

ns non-significant, * and ** indicate significant differences at $5 \%$ and $1 \%$ probability levels, respectively. TSSs $=$ total soluble solids, $\mathrm{TA}=$ titratable acidity.

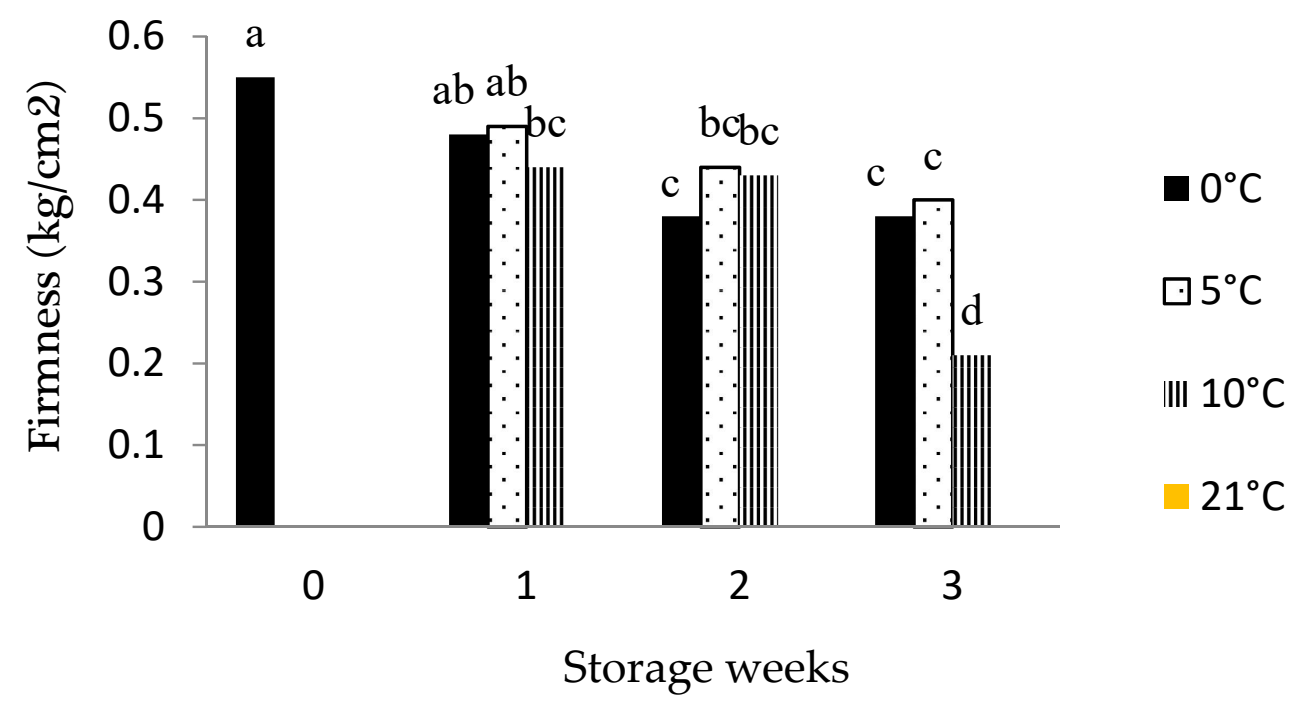

Figure 1. Effects of different storage temperatures on the fruit firmness of cornelian cherries treated with $1 \%$ chitosan. Different letters on bars indicate significant differences among storage temperatures at $p<0.01$ by Duncan's test.

\section{2. $p H$, Titratable Acidity (TA), and Total Soluble Solids (TSSs)}

Under the diverse storage temperatures, significant $(p \leq 0.01)$ differences were recorded in $\mathrm{pH}, \mathrm{TA}$, and TSS in cornelian cherry fruits (Table 1). The notable decline in TA during postharvest period (Figure 2B) could be ascribed to the conversion of organic acids and the increased content of carbohydrates [24]. 


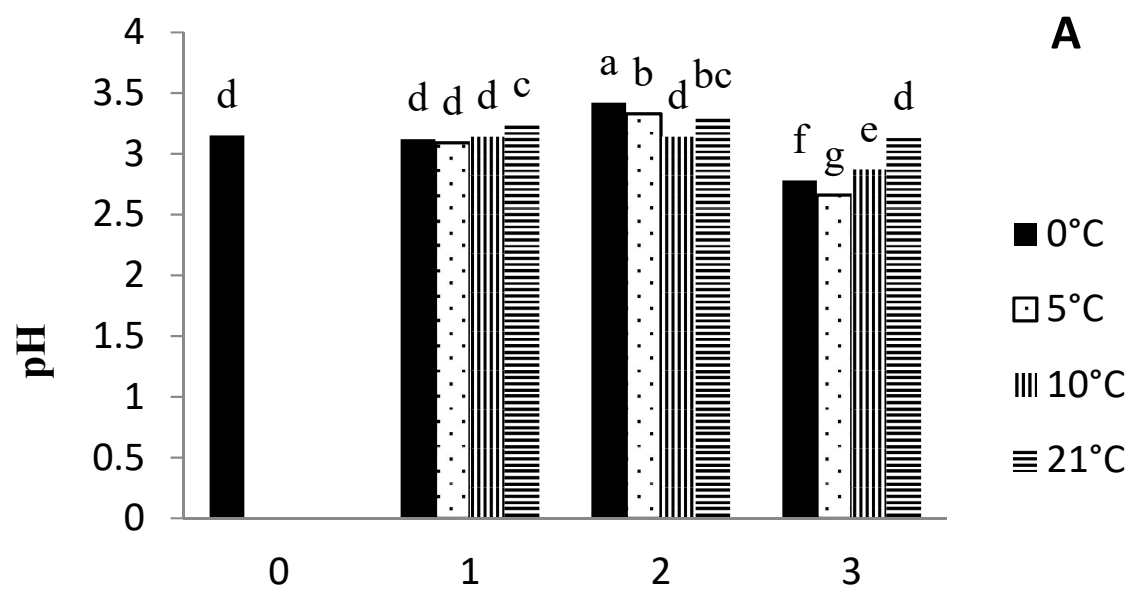

Storage weeks
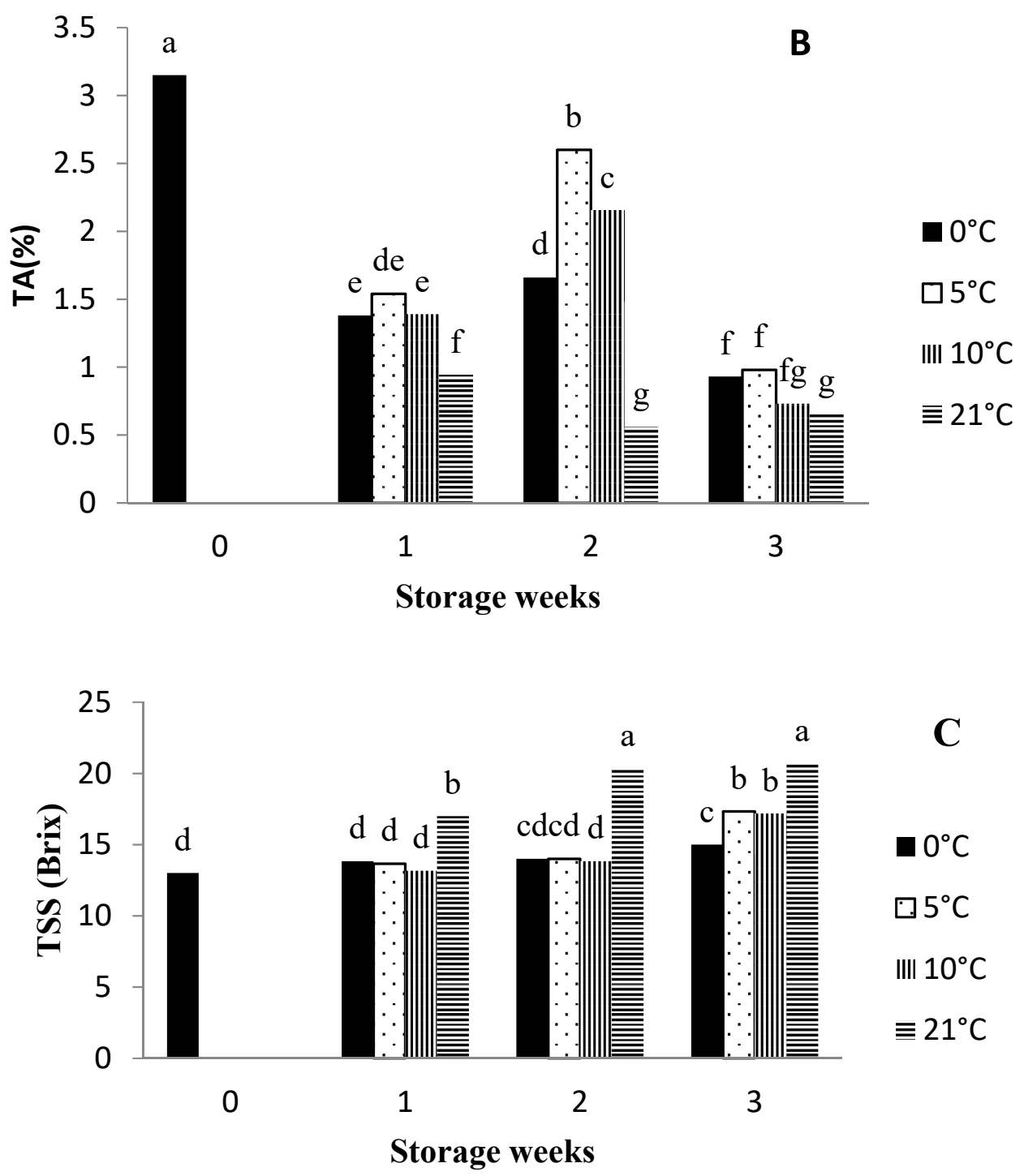

Figure 2. Effects of different storage temperatures on $\mathrm{pH}(\mathbf{A})$, titratable acidity (TA) (B), and total soluble solid (TSS) content (C) of cornelian cherry fruits treated with $1 \%$ chitosan. Different letters on bars indicate significant differences among storage temperatures at $p<0.01$ by Duncan's test. 
Other studies on the effects of storage temperature on pomegranate fruits [27] and Ziziphus [28] similarly stated that with increasing storage temperature, TA was reduced in the fruits. TA in grapefruit was decreased with high storage temperatures as well [29]. In cornelian cherry fruits, with any progress in the fruit's maturity and with darker fruits, the TSS/TA ratio was increased and fruits were palatable and more acceptable [30]. Lowtemperature storage and chitosan coating slow down the fruit ripening process [31]. Increased respiration rate under high temperatures is the dominant reason for the reduction in TSS amount as well (26). However, under lower storage temperatures, the respiration rate is decreased, leading to greater accumulation of carbohydrates in the fruit tissues [26,32].

\subsection{Fruit Color}

Fruit color-related indices, namely $\mathrm{L}^{*}$ (shining index), $\mathrm{a}^{*}, \mathrm{~b}^{*}$, hue, and chroma, were influenced by the interaction of storage temperature and time $(p \leq 0.01)$. The color is a visual and/or organoleptic marketability criterion in all fruit crops which is dominantly under genetic control. Fruit color during the ripening time is determined by the degreening (chlorophyll degradation) and the overcoming of anthocyanins and carotenoids. In cornelian cherry, anthocyanin pigments are responsible for the fruit color [33]. Our results showed a significant decline in all color indices in cornelian cherries during the storage period. However, a notable decrease was observed during the first week of storage. Similarly, in grapes treated with chitosan, $\mathrm{L}^{*}$ and hue values declined during storage. Meanwhile, the $\mathrm{L}^{*}$ value of chitosan-coated fruits was higher than that of control. Otherwise, $\mathrm{L}^{*}$ followed the reducing pattern in the storage period [34]. In strawberry fruit, $\mathrm{L}^{*}$ and hue values declined during the storage but anthocyanin content increased [25].

There was a notable decline in $\mathrm{L}^{*}$, hue, and chroma values in cornelian cherry fruits kept at higher temperatures (Table 2). The declining pattern for color indices was much greater under high temperatures [23]. The same result has been reported for tomatoes in which the best hue value was found for the highest storage temperature [35]. Hue angle declined during ripening and in zero temperature [35]. Similar data have been reported for sweet cherry in which $\mathrm{L}^{*}$, hue, and chroma were lower in ripe fruits than in unripe ones [36].

Table 2. Temperature effect on the color indices of cornelian cherry fruits treated with $1 \%$ chitosan during the storage period.

\begin{tabular}{ccccccc}
\hline Chroma & Hue & $\mathbf{b}^{*}$ & $\mathbf{a}^{*}$ & $\mathbf{L}^{*}$ & Weeks & $\begin{array}{c}\text { Temperature } \\
\left({ }^{\circ} \mathbf{C}\right)\end{array}$ \\
\hline $41.81^{\mathrm{a}}$ & $36.72^{\mathrm{a}}$ & $24.99^{\mathrm{a}}$ & $33.51^{\mathrm{a}}$ & $48.79^{\mathrm{a}}$ & 0 & \\
$29.24^{\mathrm{b}}$ & $27.97^{\mathrm{bcd}}$ & $13.67^{\mathrm{bc}}$ & $25.84^{\mathrm{b}}$ & $34.92^{\mathrm{bc}}$ & 1 & 0 \\
$27.26^{\mathrm{bcd}}$ & $25.85^{\mathrm{de}}$ & $11.86^{\mathrm{cd}}$ & $24.53^{\mathrm{b}}$ & $32.76^{\mathrm{cde}}$ & 2 & \\
$26.28^{\mathrm{b}-\mathrm{e}}$ & $23.59^{\text {ef }}$ & $10.47^{\mathrm{de}}$ & $24.085^{\mathrm{b}}$ & $30.56^{\mathrm{efg}}$ & 3 & \\
\hline $41.81^{\mathrm{a}}$ & $36.72^{\mathrm{a}}$ & $24.99^{\mathrm{a}}$ & $33.51^{\mathrm{a}}$ & $48.79^{\mathrm{a}}$ & 0 & \\
$28.91^{\mathrm{bc}}$ & $30.57^{\mathrm{bc}}$ & $14.72^{\mathrm{b}}$ & $24.88^{\mathrm{b}}$ & $35.4^{\mathrm{b}}$ & 1 & \\
$25.9^{\mathrm{c}-\mathrm{e}}$ & $21.89^{\mathrm{f}}$ & $9.59^{\text {ef }}$ & $24.03^{\mathrm{b}}$ & $31.15^{\mathrm{def}}$ & 2 & \\
$25.39^{\mathrm{de}}$ & $21.26^{\mathrm{f}}$ & $9.26^{\text {ef }}$ & $23.62^{\mathrm{b}}$ & $29.085^{\mathrm{fgh}}$ & 3 & \\
\hline $41.81^{\mathrm{a}}$ & $36.72^{\mathrm{a}}$ & $24.99^{\mathrm{a}}$ & $33.51^{\mathrm{a}}$ & $48.79^{\mathrm{a}}$ & 0 & \\
$23.97^{\mathrm{ef}}$ & $31.31^{\mathrm{b}}$ & $12.44^{\mathrm{c}}$ & $20.49^{\mathrm{cd}}$ & $28.23^{\mathrm{gh}}$ & 1 & \\
$21.58^{\mathrm{f}}$ & $22.22^{\text {ef }}$ & $8.15^{\mathrm{fg}}$ & $19.98^{\mathrm{d}}$ & $27.45^{\mathrm{h}}$ & 2 & \\
$17.99^{\mathrm{g}}$ & $22.6^{\text {ef }}$ & $6.92^{\mathrm{g}}$ & $16.6^{\mathrm{e}}$ & $27.24^{\mathrm{h}}$ & 3 & \\
\hline $41.81^{\mathrm{a}}$ & $36.72^{\mathrm{a}}$ & $24.99^{\mathrm{a}}$ & $33.51^{\mathrm{a}}$ & $48.79^{\mathrm{a}}$ & 0 & \\
$26.01^{\mathrm{c}-\mathrm{e}}$ & $27.58^{\mathrm{cd}}$ & $12.06^{\mathrm{cd}}$ & $22.97^{\mathrm{bc}}$ & $33.52^{\mathrm{bcd}}$ & 1 & \\
$22.16^{\mathrm{f}}$ & $22.38^{\text {ef }}$ & $8.44^{\mathrm{fg}}$ & $20.49^{\mathrm{cd}}$ & $28.23^{\mathrm{gh}}$ & 2 & \\
$8.52^{\mathrm{h}}$ & $22.67^{\text {ef }}$ & $3.13^{\mathrm{h}}$ & $7.9^{\mathrm{f}}$ & $22.87^{\mathrm{i}}$ & 3 &
\end{tabular}

Different letters indicate significant differences within each column based on Duncan's multiple range test at $p<0.05$. 
Chroma index variations are quite dependent upon the storage temperature and are also concomitantly related to the total anthocyanin content; thus, low-temperature refrigeration improves the color indices of fruits $[37,38]$. With the prolonged storage time and the elevated storage temperature, chroma values declined [39].

\subsection{Total Phenolic Content}

As shown in Table 3, total phenolics were affected by the storage temperature and time $(p \leq 0.01)$. During storage at all tested temperatures for 3 weeks, we recorded a significant increase in phenolic content in cornelian cherry fruits coated with $1 \%$ chitosan (Figure 3A). However, the greatest increase was observed particularly during the last week of storage under $21{ }^{\circ} \mathrm{C}$. The results showed that total phenolics were increased by time during the storage. Moreover, higher temperatures demonstrated more total phenolics during 3 weeks of storage. In the third week, higher temperatures showed a jump in total phenolic content. In a similar study, raspberry fruits stored at $10{ }^{\circ} \mathrm{C}$ had a significant increase in total phenolic content compared to $5{ }^{\circ} \mathrm{C}$, but the phenolics of samples at $0{ }^{\circ} \mathrm{C}$ were maintained in a more constant ratio throughout the storage period. Both storage time and temperature affected the phenolic content of all tested fruits [38].

Table 3. ANOVA for the total phenolics, flavonoids, antioxidant capacity, and anthocyanin content in cornelian cherry fruits treated with $1 \%$ chitosan under storage with different temperatures.

\begin{tabular}{|c|c|c|c|c|c|}
\hline \multicolumn{4}{|c|}{ MS } & \multirow[t]{2}{*}{ DF } & \multirow[t]{2}{*}{ SS } \\
\hline DPPH & Anthocyanin & TF & TP & & \\
\hline$* * 107 / 12$ & $* * 153 / 77$ & $* * 0 / 23$ & $* * 0 / 29$ & 3 & temperature \\
\hline$* * 691 / 89$ & $* * 922 / 52$ & $* * 0 / 75$ & $* * 1 / 98$ & 3 & storage time \\
\hline *28/73 & $* * 25 / 24$ & $* * 0 / 07$ & $* * 0 / 097$ & 9 & storage time $\times$ temperature \\
\hline $11 / 78$ & $1 / 88$ & 0/0039 & $0 / 008$ & 32 & error \\
\hline $8 / 36$ & $11 / 10$ & $4 / 92$ & $11 / 47$ & - & C.V. \\
\hline
\end{tabular}

Phenolics as the major secondary metabolites mediate the durability of plants under stressful conditions. Phenolics possess a very high antioxidant capacity, protect plants from stressors, and play pivotal roles in biological systems. Besides, phenolics endow the plants and their fruits with their special characteristic smell, taste, and color [38]. SoleimaniAghdam et al. [39] reported that chitosan, by activating PAL, intensified the effects of calcium chloride $\left(\mathrm{CaCl}_{2}\right)$ on fruit storability and even improved the phenolic content in cornelian cherry fruits. 

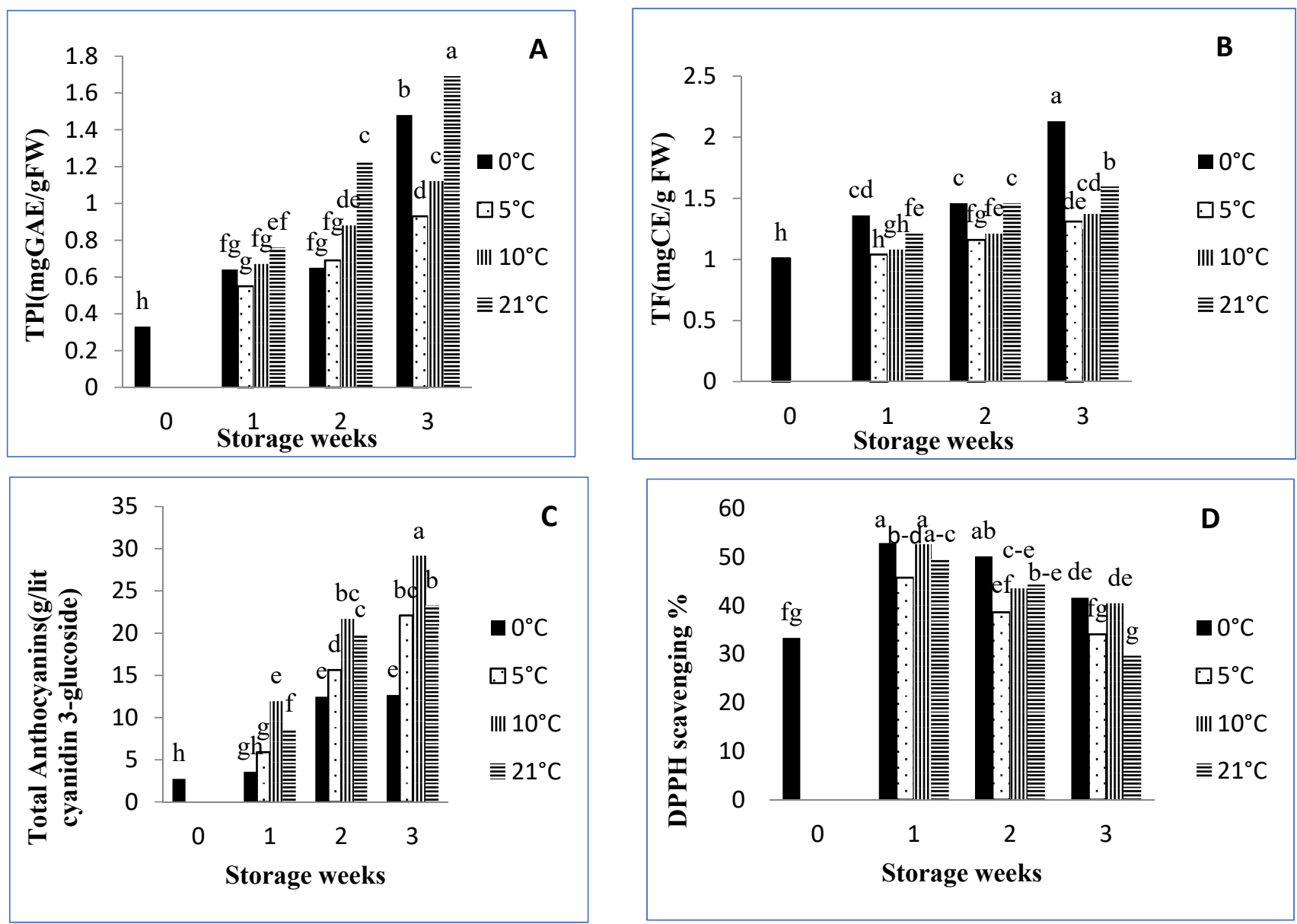

Figure 3. Effects of different storage temperatures on total phenolic (TP) content (A), total flavonoid (TF) content (B), total anthocyanin content (C), and DPPH scavenging percent (D) of cornelian cherry fruits treated with $1 \%$ chitosan. Different letters on bars indicate significant differences among storage temperatures at $p<0.05$ by Duncan's test.

\subsection{Total Flavonoids}

Flavonoid biosynthesis was induced by the storage time and temperature $(p \leq 0.01)$ (Table 3). Based on mean comparisons, the highest total flavonoid (2.139 mg of GAE per $\mathrm{g}$ fresh weight) content was observed in samples kept at $21^{\circ} \mathrm{C}$ after 3 weeks. Fruits on the first day after harvest in all tested temperatures contained the lowest total flavonoid content (1.01 mg of GAE per g fresh weight). Mean comparisons (Figure 3B) show that total flavonoids were increased during the storage. This increase was maximum for zero temperature. Considering that temperature is a key factor in flavonoid biosynthesis, cornelian cherry fruit is a rich source of phenolics, anthocyanins, and flavonoids; so, it is necessary to seek the optimal conditions to maintain these valuable compounds [6]. In another study on strawberry fruits, total flavonoids were more accumulated during storage time [38].

\subsection{Total Anthocyanins}

Total anthocyanin content was influenced by the storage time and temperature $(p \leq 0.01)$ (Table 3). Mean comparisons show that (Figure 3D) the trait was increased by the storage time. Anthocyanin content decreased at 0 and $5{ }^{\circ} \mathrm{C}$, but for the fruits stored at $10^{\circ} \mathrm{C}$, the total anthocyanin content increased dramatically.

Anthocyanin biosynthesis continues even after harvest, and several factors mediate their biosynthesis and accumulation. For example, temperature raise increases anthocyanin biosynthesis [40]. Cornelian cherry is rich in anthocyanin compounds, and these metabolites are crucial in the estimation of fruit color indices [41]. With temperature, anthocyanin 
degradation in fruits increases at such a rate that their deterioration at $22{ }^{\circ} \mathrm{C}$ is 1.8 times higher than that at $2{ }^{\circ} \mathrm{C}[36]$. $\mathrm{CaCl}_{2}$-treated cornelian cherry fruits contained the increased total phenolic, flavonoid, anthocyanin, and ascorbic acid contents [39]. In another study on strawberries, anthocyanin synthesis increased during the storage time, and the further accumulation of anthocyanins was dependent on storage temperature [40]. In sweet cherry fruits, anthocyanin content was responsive to the storage temperature and fruit ripening stage [36]. Similar results were obtained with strawberry fruit; the total anthocyanin amount was dependent on storage temperature and even increased during storage [23]. Moreover, anthocyanin accumulation was more intensified in high temperatures compared to low-temperature regimes [38].

\subsection{Total Antioxidant Activity}

Results showed that the coapplication of low temperature and chitosan pretreatment could maintain the beneficial antioxidant activity of cornelian cherries during storage time. The highest antioxidant activity $(87.52 \%)$ was observed in fruits stored at $0{ }^{\circ} \mathrm{C}$ after 7 days, and the lowest antioxidant activity $(29.65 \%)$ was observed in control samples on day 21 (Figure 3D).

A related study on strawberries showed that fruits stored at $4{ }^{\circ} \mathrm{C}$ had greater antioxidant capacity than ones kept at $25^{\circ} \mathrm{C}$ [42]. Contrarily, the antioxidant capacity of the fruits at $10^{\circ} \mathrm{C}$ declined more quickly compared to the fruits kept at 0 or $5^{\circ} \mathrm{C}$ [43]. Antioxidant capacity is a reflection of total phenolic and anthocyanin contents. In the present study, an increase in phenolic and anthocyanin contents was correlated with the antioxidant capacity of the fruit extract.

During the prolonged storage periods, the antioxidant capacity decline could be quickened by the degradation of phenolics and ascorbic acid. The reducing pattern for antioxidant capacity during the storage has been reported by Ferreyra et al. [44] in strawberry fruit as well.

\subsection{Antioxidant Enzyme Activity}

\subsubsection{Catalase}

CAT activity directly declined with storage time and temperature $(p \leq 0.01)$. Mean comparison (Figure 4) for catalase activity follows a declining pattern during storage and for all temperature regimes. Catalase is a prevailing enzyme in nearly all organic tissues scavenging $\mathrm{H}_{2} \mathrm{O}_{2}$ into water and $\mathrm{O}_{2}$ and protects cells from the peroxidation dangers of $\mathrm{H}_{2} \mathrm{O}_{2}[45,46]$.
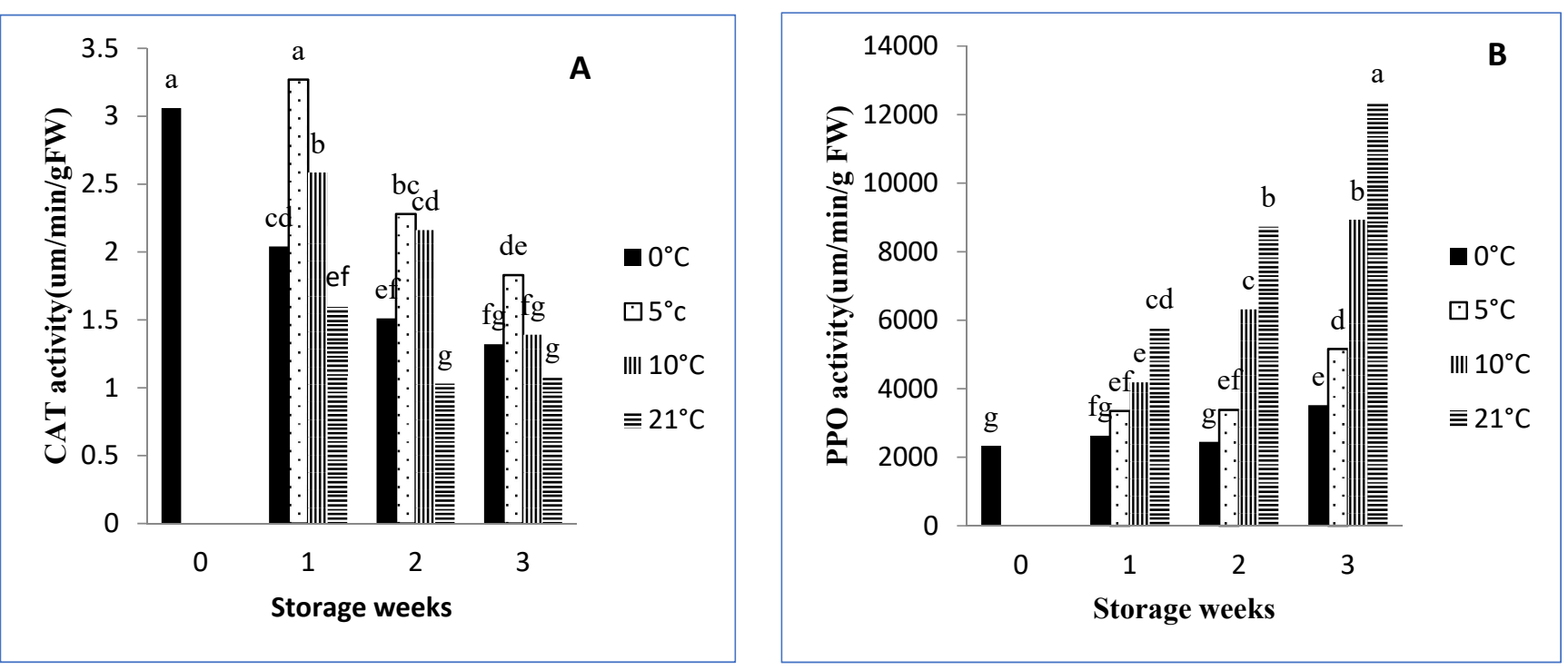

Figure 4. Cont. 

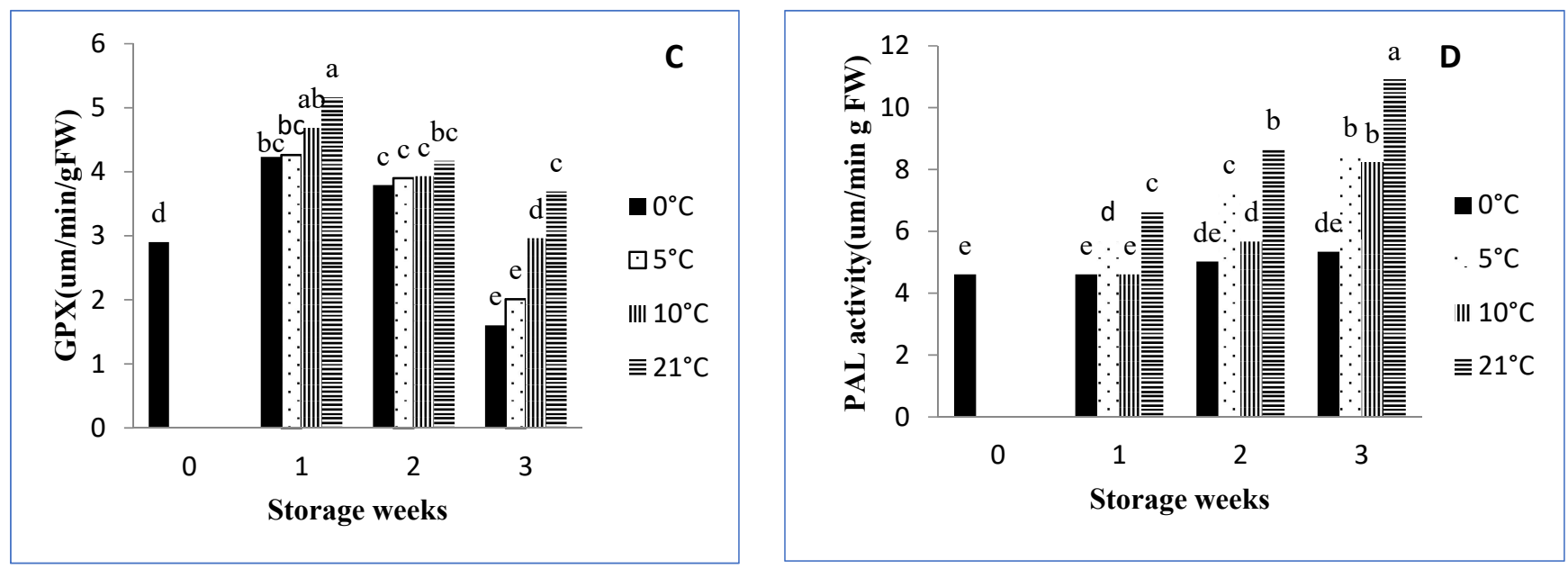

Figure 4. Effects of different storage temperatures on catalase (A), polyphenol oxidase (B), guaiacol peroxidase (C), and phenylalanine ammonia-lyase (D) activities of cornelian cherry fruits treated with $1 \%$ chitosan. Different letters on bars indicate significant differences among storage temperatures at $p<0.05$ by Duncan's test.

As shown in Figure $4 \mathrm{~A}, \mathrm{CAT}$ activity in higher temperatures $\left(10\right.$ and $\left.21^{\circ} \mathrm{C}\right)$ was increased continuously during storage and was much higher at $21^{\circ} \mathrm{C}$ compared to other tested temperatures $\left(0\right.$ and $\left.5^{\circ} \mathrm{C}\right)$. This suggests that CAT plays a key role in the metabolic responses of cornelian cherries to the temperature. Our results were consistent with previous reports on strawberries [43] where catalase activity declined in fruits during storage and under 5 and $10^{\circ} \mathrm{C}$.

\subsubsection{PPO Activity}

PPO activity was statistically $(p \leq 0.01)$ influenced by the storage temperature and time. Mean comparisons revealed that (Figure 4), with temperature rise and during the storage time, PPO activity was increased. Hence, the highest $(17,341)$ and the lowest $(2141)$ levels of PPO activity were observed in fruits stored at room temperature on day 21 and in samples stored at $5{ }^{\circ} \mathrm{C}$ on day 7 , respectively.

The results are consistent with a finding in pineapple where $\mathrm{PPO}$ activity was increased with the raised temperature and during the storage time [47]. PPO is the key enzyme in enzymatic browning and a dominant factor in phenolic oxidation [48]. Enzymatic browning via phenolic oxidation and conversion to quinone is dependent upon the PPO and oxygen presence [48]. PPO activity in the fruits is controlled by the harvest time, temperature, gaseous environment, and other environmental conditions [49]. Respiration, nutrient availability, fruit tissue firmness, and the antioxidant pool influence PPO activity [49].

$\mathrm{PPO}$ activity declined with low $\mathrm{pH}$ values, and the conditions that maintain the organic acid pool reduce PPO activity [49]. During the postharvest and storage period, PPO activity increases coincide with the ripening and senescence of fruits. These biochemical and physiological changes result in tissue browning, unappealing odor and/or taste, and the great loss in nutritious quality of fruits [50].

\subsubsection{GPX Activity}

Results show the significance of GPX activity in cornelian cherry fruits with storage temperatures and time $(p \leq 0.01)$. Figure 4 shows that during the storage and with the increase in temperature, GPX activity was increased. At the end of storage, GPX activity at $21^{\circ} \mathrm{C}$ was 2.04 times higher than that at zero temperature. Variation in the activity of the antioxidant enzymes and their pure amount is thoroughly acceptable in response to the storage temperature. However, the magnitude of the variations and the subsequent related metabolic responses are quite dependent upon the enzyme type, its gross amount, the related compound dynamics, and the environmental and storage conditions. 


\subsubsection{PAL Activity}

PAL is a chief enzyme in the regulation of phenylpropanoid metabolism, which produces trans-4-hydroxy cinnamate [51]. With increasing PAL activity, the biosynthesis and accumulation of phenolics are stimulated, and hence, the plant tissues become more tolerant to the biotic and abiotic stressors [52]. In our experiment, PAL activity was significantly $(p \leq 0.01)$ different between treatments. PAL activity had an ascending pattern with temperature during the storage period, and the highest activity was found at room temperature $\left(21^{\circ} \mathrm{C}\right)$ (Figure 4). Low temperatures stimulate PAL and encourage browning and color alteration as well. In another study on bananas, storage at $6{ }^{\circ} \mathrm{C}$ resulted in increased PAL activity compared to $10^{\circ} \mathrm{C}$ [19]. Furthermore, in raspberry fruits coated with Aloe vera gel and under storage at $4{ }^{\circ} \mathrm{C}$ for 8 days, PAL activity was increased during the storage time-course [53].

\section{Conclusions}

Cornelian cherry fruits are rich in bioactive compounds such as phenolics, flavonoids, and anthocyanins. However, like other perishable fruits, the nutritional quality of cornelian cherry fruits declines during the postharvest period. Chitosan coating greatly influences the nutritional value of fruits, and low-temperature storage is a preferential method for prolonging the shelf and storage life and postharvest quality of horticultural produce. In the present study, quality attributes and physiological characteristics of cornelian cherry fruits were affected by the storage temperature and time. Storage under high temperature, due to the elevated respiration rate, accelerated ripening process and negatively impacted the quality attributes of fruits in the main part due to the fruits' firmness loss. In contrast, fruits stored under low-temperature regimes attained more suitable quality attributes and especially superior antioxidant activity. Furthermore, the results showed that antioxidant enzymes (CAT, GPX, PPO, and PAL) may participate less in ROS scavenging of cornelian cherry fruits stored at 0 and $5{ }^{\circ} \mathrm{C}$ than in that of those stored at higher temperatures $\left(10\right.$ and $\left.21^{\circ} \mathrm{C}\right)$, and chitosan application could probably improve the antioxidant capacity. Our data indicate that the coapplication of physicochemical treatments (chitosan coating followed by temperature treatment) was effective in preserving the postharvest quality attributes of cornelian cherry fruits. Therefore, we suggest that pretreatment with chitosan (1\%) in combination with storage at low temperature might be a useful and more efficient way to expand the shelf life and preserve the nutritional quality of cornelian cherry fruits during storage.

Author Contributions: Conceptualization, A.E., H.H. and M.E.; data curation, A.E. and M.E.; formal analysis, A.E., M.E., L.D. and M.B.H.; methodology, M.E. and H.H.; project administration, A.E. and H.H.; visualization, A.E., M.E., M.B.H., M.R.B., L.D., J.M. and S.E.; writing-original draft, A.E., M.E., M.B.H., S.E. and H.H.; writing-review and editing, S.E., L.D., J.M. and M.B.H. All authors have read and agreed to the published version of the manuscript.

Funding: This study was funded by the University of Maragheh and Urmia University, Iran, and Mendel University in Brno, Czech Republic.

Institutional Review Board Statement: Not applicable.

Informed Consent Statement: Not applicable.

Data Availability Statement: All new research data were presented in this contribution.

Acknowledgments: This study was carried out at the University of Maragheh and Urmia University, Iran. The research was supported by program No. 6.2.10 ref. 51834/2017-MZE-17253, sub-program, National Program of Conservation and Utilization of Plant Genetic Resources and Agrobiodiversity, funded by the Ministry of Agriculture of the Czech Republic.

Conflicts of Interest: The authors declare that they have no conflict of interest. 


\section{References}

1. Wang, H.; Cao, G.; Prior, R.L. Total antioxidant capacity of fruits. J. Agric. Food Chem. 1996, 44, 701-705. [CrossRef]

2. Heinonen, I.M.; Meyer, A.S.; Frankel, E.N. Antioxidant activity of berry phenolic on human low-density lipoprotein and liposome oxidation. J. Agric. Food Chem. 1998, 46, 4107-4112. [CrossRef]

3. Rimm, E.B.; Aschiero, A.; Giovannucci, E.; Spiegelman, D.; Stampfer, M.J.; Willett, W.C. Vegetables, fruit, and cereal fiber intake and risk of coronary heart disease among men. J. Am. Med. Assoc. 1996, 275, 447-451. [CrossRef] [PubMed]

4. Seeram, N.P.; Schutzki, R.; Chandra, A.; Nair, M.G. Characterization, quantification, and bioactivities of anthocyanins in Cornus species. J. Agric. Food Chem. 2002, 50, 2519-2523. [CrossRef]

5. Hassanpour, H.; Hamidoghli, Y.; Samizadeh, H. Estimation of genetic diversity in some Iranian cornelian cherries (Cornus mas L.) accessions using ISSR markers. Biochem. Syst. Ecol. 2013, 48, 257-262. [CrossRef]

6. Pantelidis, G.E.; Vasilakakis, M.; Manganaris, G.A.; Diamantidis, G.R. Antioxidant capacity, phenol, anthocyanin and ascorbic acid contents in raspberries, blackberries, red currants, gooseberries and Cornelian cherries. Food Chem. 2007, 102, 777-783. [CrossRef]

7. Pawlowska, A.M.; Camangi, F.; Braca, A. Quality-quantitative analysis of flavonoids of Cornus mas L. (Cornaceae) fruits. Food Chem. 2010, 119, 1257-1261. [CrossRef]

8. Redzic, S. Wild medicinal plants and their usage in traditional human therapy (Southern Bosnia and Herzegovina, W. Balkan). J. Med. Plants Res. 2010, 4, 1003-1027.

9. Mamedov, N.; Craker, L.E. Cornelian cherry: A prospective source for phytomedicine. In Proceedings of the XXVI International Horticultural Congress: The Future for Medicinal and Aromatic Plants, Toronto, ON, Canada, 11-17 August 2002; Volume 629, pp. 83-86.

10. Yousefpour Dokhanieh, A.; Solaeimani Aghdam, M.; Rezapour Fard, J.; Hassanpour, H. Postharvest salicylic acid treatment enhances antioxidant potential of cornelian cherry fruit. Sci. Hort. 2013, 154, 31-36. [CrossRef]

11. Jianglian, D.; Shaoying, Z. Application of chitosan based coating in fruit and vegetable preservation: A review. J. Food Process. Technol. 2013, 4, 227-230. [CrossRef]

12. Ali, A.; Muda Muhammad, M.T.; Sijam, K.; Siddiqui, Y. Potential of chitosan coating in delaying the postharvest anthracnose (Colletotrichum gloeosporioides Penz.) of Eksotika II papaya. Int. J. Food Sci. Technol. 2010, 45, 2134-2140. [CrossRef]

13. Ali, A.; Mohamed, M.T.M.; Siddiqui, Y. Control of anthracnose by chitosan through stimulation of defence-related enzymes in Eksotika II papaya (Carica papaya L.) fruit. J. Biol. Life Sci. 2012, 3, 114-126. [CrossRef]

14. EL Ghaouth, A.; Arul, J.; Ponnampalam, R.; Boulet, M. Use of chitosan coating to reduce water loss and maintain quality of cucumber and bell pepper fruits. J. Food Process. Preserv. 1991, 15, 359-368. [CrossRef]

15. Ali, A.; Zahid, N.; Manickam, S.; Siddiqui, Y.; Alderson, P.G. Double Layer Coatings: A new technique for maintaining physicochemical characteristics and antioxidant properties of dragon fruit during storage. Food Bioprocess Technol. 2014, 7, $2366-2374$. [CrossRef]

16. Esmaili, M.; Ebrahimzadeh, A.; Hassanpour, H.; Hassanpour Aghdam, M.B. The effects of different chitosan concentrations on storage life and postharvest quality of cornelian cherry (Cornus mass L.). J. Food Res. 2020, 29, 139-152. (In Persian)

17. Selcuk, N.; Erkan, M. The effects of 1-MCP treatment on fruit quality of medlar fruit (Mespilus germanica L. cv. Istanbul) during long term storage in the palliflex storage system. Postharvest Biol. Technol. 2015, 100, 81-90. [CrossRef]

18. Chiou, M.J.; Wang, Y.D.; Kuo, C.M.; Chen, J.C.; Chen, J.Y. Functional Analysis of Mitogen-Activated Protein Kinase-3 (MAPK3) and Its Regulation of the Promoter Region in Zebrafish. DNA Cell Biol. 2007, 26, 781-790. [CrossRef]

19. Giusti, M.M.; Wrolstad, R.E. Characterization and measurement of anthocyanins by UV-visible spectroscopy. Curr. Protoc. Food Anal. Chem. 2001, 1-13. [CrossRef]

20. Shin, Y.; Liu, R.H.; Nock, J.F.; Holliday, D.; Watkins, C.B. Temperature and relative humidity effects on quality, total ascorbic acid, phenolics and flavonoid concentrations, and antioxidant activity of strawberry. Postharvest Biol. Technol. 2007, 45, 349-357. [CrossRef]

21. Aebi, H. Catalase in vitro. Meth. Enzymol. 1984, 105, 121-126.

22. Nguyen, T.B.T.; Ketsa, S.; van Doorn, W.G. Relationship between browning and the activities of polyphenol oxidase and phenylalanine ammonia lyase in banana peel during low temperature storage. Postharvest Biol. Technol. 2003, 30, 187-193. [CrossRef]

23. Upadhyaya, A.; Sankhla, D.; Davis, T.D.; Sankhla, N.; Smith, B.N. Effect of paclobutrazol on the activities of some enzymes of activated oxygen metabolism and lipid peroxidation in senescing soybean leaves. J. Plant Physiol. 1985, 121, 453-461. [CrossRef]

24. Pasquariello, M.S.; DiPatre, D.; Mastrobuoni, F.; Zampella, L.; Scortichini, M.; Petriccione, M. Influence of postharvest chitosan treatment on enzymatic browning and antioxidant enzyme activity in sweet cherry fruit. Postharvest Biol. Technol. 2015, 109, 45-56. [CrossRef]

25. Shin, Y.; Ryu, J.A.; Liu, R.H.; Nock, J.F.; Watkins, C.B. Harvest maturity, storage temperature and relative humidity affect fruit quality, antioxidant contents and activity, and inhibition of cell proliferation of strawberry fruit. Postharvest Biol. Technol. 2008, 49, 201-209. [CrossRef]

26. Valero, D.; Serrano, M. (Eds.) Postharvest Biology and Technology for Preserving Fruit Quality, 1st ed.; CRC Press: Boca Raton, FL, USA, 2009; pp. 7-47. 
27. Fawole, O.A.; Opara, U.L. Changes in physical properties, chemical and elemental composition and antioxidant capacity of pomegranate (cv. Ruby) fruit at five maturity stages. Sci. Hortic. 2013, 150, 37-46. [CrossRef]

28. Tembo, L.; Chiteka, Z.A.; Kadzere, I.; Akinnifesi, F.K.; Tagwira, F. Storage temperature affects fruit quality attributes of Ber (Ziziphus mauritiana Lamk.) in Zimbabwe. Afr. J. Biotechnol. 2008, 7, 3092-3099.

29. Pailly, O.; Tison, G.; Amouroux, A. Harvest time and storage conditions of 'Star Ruby'grapefruit (Citrus paradisi Macf.) for short distance summer consumption. Postharvest Biol. Technol. 2004, 34, 65-73. [CrossRef]

30. Demir, F.; Kalyoncu, I.H. Some nutritional, pomological and physical properties of cornelian cherry (Cornus mas L.). J. Food Eng. 2003, 60, 335-341. [CrossRef]

31. Thumula, P. (Ed.) Studies on Storage Behavior of Tomatoes Coated with Chitosan-Lysozyme Films; McGill University: Montréal, QC, USA, 2006.

32. Ayala-Zavala, J.F.; Wang, S.Y.; Wang, C.Y.; González-Aguilar, G.A. Effect of storage temperatures on antioxidant capacity and aroma compounds in strawberry fruit. LWT-Food Sci. Technol. 2004, 37, 687-695. [CrossRef]

33. Bianca, M.; Luminita, D. Influence of temperature and preserving agents on the stability of Cornelian cherries anthocyanins Molecules 2014, 19, 8177-8188.

34. Sánchez-González, L.; Pastor, C.; Vargas, M.; Chiralt, A.; González-Martínez, C.; Cháfer, M. Effect of hydroxy propylmethylcellulose and chitosan coatings with and without bergamot essential oil on quality and safety of cold-stored grapes. Postharvest Biol. Technol. 2011, 60, 57-63. [CrossRef]

35. Shewfelt, R.L.; Thai, C.N.; Davis, J.W. Prediction of changes in color of tomatoes during ripening at different constant temperatures. J. Food Sci. 1988, 53, 1433-1437. [CrossRef]

36. Gonçalves, B.; Silva, A.P.; Moutinho-Pereira, J.; Bacelar, E.; Rosa, E.; Meyer, A.S. Effect of ripeness and postharvest storage on the evolution of color and anthocyanins in cherries (Prunus avium L.). Food Chem. 2007, 103, 976-984. [CrossRef]

37. Rodriguez-Saonm, L.E.; Giusti, M.M.; Wrolstad, R.E. Color and pigment stability of red radish and red-fleshed potato anthocyanins in juice model systems. J. Food Sci. 1999, 64, 451-456. [CrossRef]

38. Rezaee Kivi, A.; Sartipnia, N.; Babai Khalkhali, M. Comparative phenolic content and antioxidant activities of four wild raspberries in Iran. J. Appl. Sci. Agric. 2014, 9, 2419-2424.

39. Soleimani-Aghdam, M.; Yousefpour-Dokhanieh, A.; Hassanpour, H.; Pezapour-Fard, J. Enhancement of antioxidant capacity of cornelian cherry (Cornus mas L.) fruit by postharvest calcium treatment. Sci. Hortic. 2013, 161, 160-164. [CrossRef]

40. Cordenunsi, B.R.; Genovese, M.I.; doNascimento, J.R.O.; Hassimotto, N.M.A.; dosSantos, R.J.; Lajolo, F.M. Effects of temperature on the chemical composition and antioxidant activity of three strawberry cultivars. Food Chem. 2005, 91, 113-121. [CrossRef]

41. Celik, S.; Bakirci, I.; Sat, I.G. Physico-chemical and organoleptic properties of yogurt with cornelian cherry paste. Int. J. Food Prop. 2006, 9, 401-408. [CrossRef]

42. Piljac-Žegarac, J.; Šamec, D. Antioxidant stability of small fruits in postharvest storage at room and refrigerator temperatures. Food Res. Int. 2011, 44, 345-350. [CrossRef]

43. Wang, S.Y.; Gao, H. Effect of chitosan-based edible coating on antioxidants, antioxidant enzyme system, and postharvest fruit quality of strawberries (Fragaria $x$ aranassa Duch.). LWT-Food Sci. Technol. 2013, 52, 71-79. [CrossRef]

44. Ferreyra, R.M.; Viña, S.Z.; Mugridge, A.; Chaves, A.R. Growth and ripening season effects on antioxidant capacity of strawberry cultivar Selva. Sci. Hortic. 2007, 112, 27-32. [CrossRef]

45. Chelikani, P.; Fita, I.; Loewen, P.C. Diversity of structures and properties among catalases. Cell. Mol. Life Sci. 2004, 61, 192-208. [CrossRef] [PubMed]

46. Sala, J.M.; Lafuente, M.T. Catalase enzyme activity is related to tolerance of mandarin fruits to chilling. Postharvest Biol. Technol. 2000, 20, 81-89. [CrossRef]

47. Hong, K.; Xu, H.; Wang, J.; Zhang, L.; Hu, H.; Jia, Z.; Gu, H.; He, Q. Quality changes and internal browning developments of summer pineapple fruit during storage at different temperatures. Sci. Hortic. 2013, 151, 68-74. [CrossRef]

48. Mayer, A.M. Polyphenol oxidases in plants-recent progress. Phytochemistry 1987, 26, 11-20. [CrossRef]

49. Ruoyi, K.; Zhifang, Y.; Zhaoxin, L. Effect of coating and intermittent warming on enzymes, soluble pectin substances and ascorbic acid of Prunus persica (cv. Zhonghuashoutao) during refrigerated storage. Food Res. Int. 2005, 38, 331-336. [CrossRef]

50. Goupy, P.; Amiot, M.J.; Forget, F.; Duprat, F.; Aubert, S.; Nicolas, J. Enzymatic browning of model solutions and apple phenolic extracts by apple polyphenol oxidase. J. Food Sci. 1995, 60, 497-501. [CrossRef]

51. Ritter, H.; Schulz, G.E. Structural basis for the entrance into the phenylpropanoid metabolism catalyzed by phenylalanine ammonia-lyase. Plant Cell 2004, 16, 3426-3436. [CrossRef] [PubMed]

52. Elyatem, S.M.; Kader, A. Post-harvest physiology and storage behavior of pomegranate fruits. Sci. Hortic. 1984, 24, 287-298. [CrossRef]

53. Hassanpour, H. Effect of Aloe vera gel coating on antioxidant capacity, antioxidant enzyme activities and decay in raspberry fruit. LWT-Food Sci. Technol. 2015, 60, 495-501. [CrossRef] 